しておき，必要の都度最も適当なものを検索の対象とし てえらぶことができれば理想的である。

この点C.P.I. は，特定のセクションに限られてはい るがマニュフルコードとパンチコードといら全く異なる 分類体系を用いて，カードや磁気テーブで検索できるシ ステムを準借しているはか，国祭特許分類や，米国特許 庁分類 C.P.I. クラスなど幾つかの分類を併記して，利 用者に選択利用の便宜を与えていることは賢明であり， システムの価値を高めていると思う。

(c) 速報資料炡てて

2 種類の抄録誌は速報誌として絾にすぐれたるのでは あるが，セクション別化編集されているため，カテゴリ 一が大き過ぎ、これをそのままニース誌として利用す るには適当でない。この抄録誌は, ニュース誌であると 同時に検索した後の内容チェック用として重要な意味を もっているので, 番号から抄録への到達のしやすさに重 点を置くのあまり，上記の欠点を助長する結果となった のは扎しれる。その対策としてC.P.I. クラスインデ ックスやマニュアルコードインデックスなどが用意され ているが，その意味ではあまり効果的とは思えない。

(d) 挨索の手段

ノンバンチ方式の手検索カードが 2 種類用意されてい
るのは, ヨーロッパ各社の要求傾向を示すむのであろう か。

実際に利用してみるとそれほど検索効率は悪くなく， 非常に安価なので，堅実な利用手段として評価すへきで あろら。ソーターを用いるカード検索方式は時流炕乗っ たシステムとはいい難いとしてダーウェント社は磁気テ ープの利用を推奖している。磁気テーブは検索時間の短 縮を考虑し，検索テープとビブリオテープに分かれてい る。最も一般的になってきた IBM 360 用に作られたブ ロダラムる準備されているので，自家検索する場合は便 利であるが，検索コストが高くつくので，調査件数がよ ほど多い場合は別として，ちゅうちょせざるをえない。 利用効率を高める意味でリサーチセンターによる共同利 用体制が理想的であろら。

\section{むす ひ}

ダーウェント社の C. P.I. は自社システムを検討する 際にも大変参考になると思らのでご紹介したが，紙面の 都合で充分な説明ができなかったことを扮詫びします。 特許情報の特殊性と合わせてこ理解いただき，何かの 拉役に立てば幸甚です。

\title{
化学工業プロジェクト支援
}

\section{のための電算機サービス体制*}

\section{1. 化学工業プロジェクト}

設備の大型化, 市場の競合, 技術の急速な進歩, あ るいは最近の我国に拈ける急速な社会の变化など最近の 情勢はプロジェクトの業務をはなはた難かしいるのにし ている。この中で電算機がどのような役割を果たしらる か, したがってそれはどのような機能を持たねばならな いか私見を述べ，その中で本特集の趣旨である情報検索 のためのシステムにつき，2〜3の例を紹介したい。

图 1 に一般的な化学工業ブロジェクトの進行を概念的

* 昭和 45 年 9 月 14 日受理

** Kiyoshi Tomita 味の素(株) 隶務合理化空

\section{雷 田潔**}

に示した。技術サイドでは主として経済的生産を中心 課題に, ラボラトリーからベンチプラント，ハイロット ブラントへと規模を拡大しつつ, 本格生産へと移行して いく。一方販壳サイドでも並行して調査, 利用研究, 試 験販売, 本格販売へと研究と払大が進行していく。試料 の提供, 品質への要求, と両者は関連を持ちつつ, 企業 の長期計画に基つくく適正な評価体系を軸として両輪のご とく管理されていかねばならない。

単に設計・建設といら場面だとらえても，プロジェ クトはきわめて多くの単位業務の総合から成り立つむの であろらが，上記観点にたつなら更に市場の研究，社 会・経済の見通し，技術情報の把握・予測といった総合 
的企画力との結びつきの中で進行管理されるむのでなけ ればならない。

プロジェクトの期間は $2 \sim 3$ 年か, 長いすのでは 10 年 といらようなるのああ万う。そして通常の企業において は常時数十の大小, また種々の進行状態にある雑多なつ ロシェクトを同時にかかえ，多くの人々がこれに従事し ている。

\section{2. ブロジェクトのための電算機サービスの展閵}

前節に述べた通りフフロシェクトに関連する広範な業 務領域に対し，個々の担当者に，研究管理に，あるいは 意志決定に計算機のサービスが提供され, それらの効率 向上が計られねばならない。その展開は事務計算と異な った困難性を持っている。守備箐囲は広くかつ不定で, 要求はランダムである。このような中で検討の迅速性と 精緻さといら元来相容れない要素を満足させていかねば ならない。

計算機利用の初期の頃は計算機のごく周边に有能な解 析担当者を配し，彼らの作業によって様々な周辺の要望 飞応えていたが，実績によると十数名のスタッフで，問 題処理件数は年間数十といらところであり，その効果は 広筮なブロジェクト業務の中に拡散し，効率化を㩆著な あのとするにはあまりにも微力であった。

最近は計算機技術の進歩・普及により，いわゆる計算 機人口の増加にともない，各業務担当者がそれぞれ自ら 計算機を利用できる状態になって来た。したがって計 算機の運営もそのような体制に移行しつつある。たと兄 ばMACシステムなどはその最も進歩した形と考えられ る。しかし計算機の利用がある目的をるって展開せね就 ならぬ時，当然そこには課題が生ずる。

プロシェクトの業務から見て計算機がいかなる仕事を こなせばその生産性向上に奇与できるか，また計算機の 面からそれを姏理する効率をどのよらな工夫で確保すれ ば良いか，この二つの面がプロジェクトに用いられる計 算機の主要な課題である。

前者隹対しては

1. プロジェクト管理への適用

2. ブロジェクトの個々の構成業務効率化のための適用

に大別し，1.のためには計算機に近い所に管理スタッ フを配し，2. に対しては各担当者に計算機々能を直接 オープン利用せしめる。

後者の計算機面での効率化については, ブロシェクト に対して沉用性の高いアブリケーションの開発蓄積とい らことが有効で, これらアブリケーションの重点は, 一 に高度な解析力, そして二に情報の蓄積利用，というこ とにあるが，前者については以前シミュレーションを中

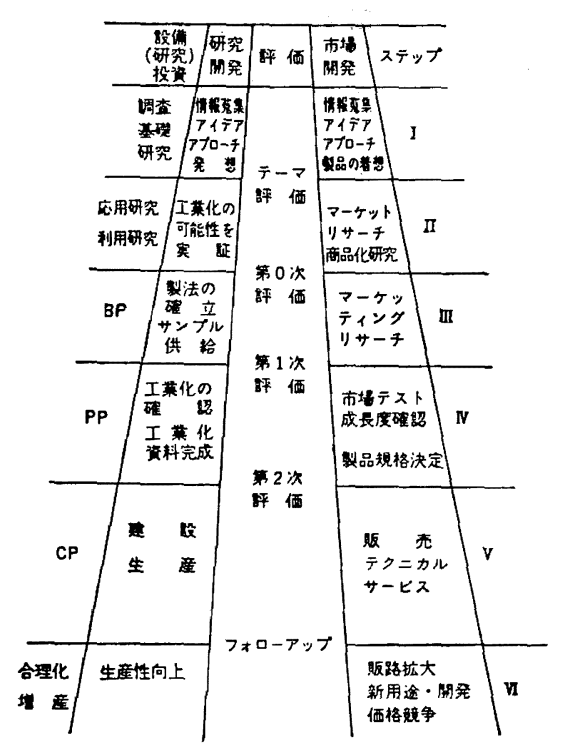

园 1 化学工業プロジェクトの進行

心に本誌りで述べたことがあるので，今回は後者，情報 検索関係に重点を置きたい。

\section{3. プロジェクト業務における情報の萿税と利用}

データの蓄積といらことに対し，MIS といら立場から データベースの概念がよく論議される。これは集団ディ スクなど大容量の補助記憶装置の発展およびそのための ソフトウェア技術の上からもきわめて興味深い分野で あり、計算機の適用いかんではたいへん有効なすのであ る。しかしながらフフロジェクトの業務にこれをいかに 使いこなして行くか，経济的な問題も含みその適用には 困難性がある。どのよらなブロジェクトがとび出すかわ からない。そのブロジェクトで何が問題の焦点になるか は千差万別であろらし，またその進行に従ってそれは逐 次変転していこう。したがってそこで必要とされるデー 夕も項目, 性質, 取り扱い方なと総合的に確定組織化す ることは難かしい。

特に重要なことは通常の事務計算の場合のように, デ 一タが日常の事務の流れの中で自動的に更新され, 蓄積 される、といらものがきわめて少なく, 外部の情報源から 特別飞意識的に維持していかねばならない場合が多い, ということである。これはたいへん努力を要することで あり，費用，人手を惜しんでは出来ることでない。確実 な利益の裹付けのもとに, かつブロジェクトという仕事 の一見きまぐれさを充分認識の上で計画されていなけれ ばならない。

差し迫った要望と以上の要件の間で現実的には以下の 


\section{図 2 ERPSの入力例}

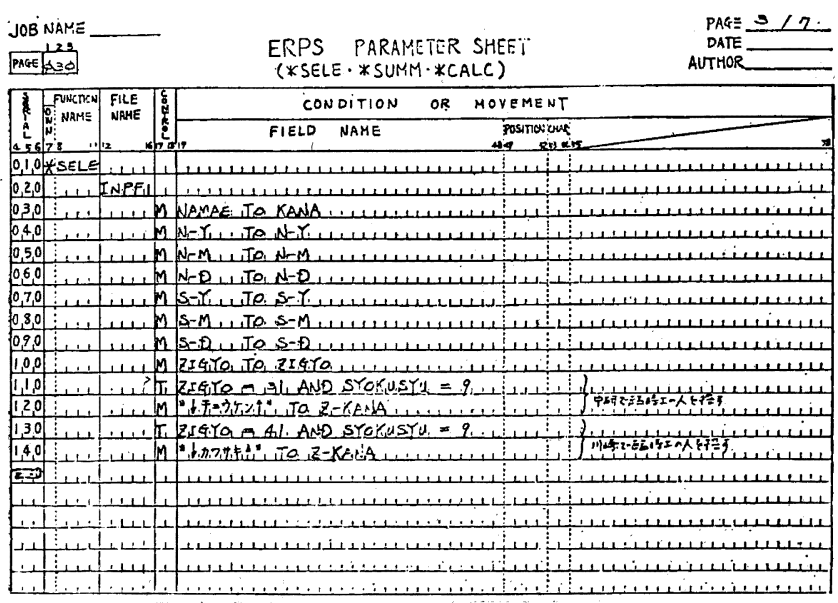

のファイルから抽出整理して, 建設費推定 の基礎資料を作成するとか，販売実績デー タの解析により，需要推定のための情報を 得る，といった例から理解されよう。

ERPS はプリコムパイラーとして作成さ れている。すなわち, ERPSの入力様式で 記述された情報の抽出加工の希望を計算機 が読みとり，必要な COBOL プロクラムを 出力する。これをコンパイルすることによ り，目的の仕事を果たすことができる。直 接オブジェクトプログラムをぜネレートす るやり方に比べて，まわりくどいことは事 実であるが, プリュムパイラーの形をとる ことにより機能の融通珄を確保することが できこの面を重視した。

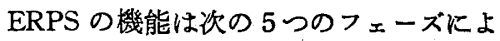

節で述べるような様々の形体の検索システムが作成使用 されるようになった。これらシステムは、シミュレーシ ョンなどアプリヶーションプログラムの作成で考えて来 たように，機能の特長，汎用性に着目しつつ，標準的な 機能を準備し, その使用は一般研究・開発担当者, ある いは情報サービス担当者にゆだねるいというような考え 方のもとに準備されたものである。磁気テープベースの 中型計算機でかかる運用を行ならことは計算機効率の上 で問題がないではないが，提供しらる機能と，教育でカ バーしていく方針で現在に至っている。

\section{4. 種々の情報検索システム}

以下味の素（株）において使用されている幾つかの情 報検索システムを紹介寸るが，それぞれ以下のごときデ 一タ利用の場を特長として準備されたものである。

1）事務システムのデータフォイルからデータの抽出利用

2）専門部門単位での小型のデータフォイリング ERPS

3）加工解析（統計的）を目的としたデータフフイル IRSYM

…........GIRLS, FOREST

4）文献の管理と検索 DIA

5）その他特殊用途のためのデータの蓄皘

\section{1 ERPS $^{2)}$}

事務システムのファイルから必要な情報を抽出し, 加 工・編集して報告を作成することを目的とするプログラ ムである。通常の事務システムからプロジェクトへの情 報の提供は要望も多く，またきわめて有効なものである。 プロジェクトが企業の将来に向って実行されるものな ら，これは企業の現状の認識に立脚して行なわれるべき あのであることはいらまですない。現実的には固定資産
り代表されこれらをモニターにより任意に組み合わせる ことができる。

\section{1）ファイルの定義と転記}

事務計算の通常の磁気テープファイルから ERPS 用 のワークテープに内容を転記するために両ファイルのレ コードの定義を行なう。入力テープは 5 種類まで同時に 取り扱らことができる。

2）データの選択

入カファイルから ERPS ファイルに内容をらつすと き，入カファイル上のデータを条件を付すことにより選 択することができる。データ検索の本体である。条件は 次のように記述する。
$\mathrm{A}=\mathrm{B}: \mathrm{A}$ が $\mathrm{B}$ 等しい
$A \neq B ： A$ と $B$ が不等
$\mathrm{A}>\mathrm{B}: \mathrm{A}$ は $\mathrm{B}$ より大
$\mathrm{A}<\mathrm{B}: \mathrm{A}$ は $\mathrm{B}$ より小
$A>=B: A \geqq B$
$\mathrm{A}<=\mathrm{B}: \mathrm{A} \leqq \mathrm{B}$
A OR B: A $B$
A AND B : A および B

3) 分類集計

選択されたデータを分類集計する。分類の方法, 分類 キーの名前，その位置，語長などを指定せねばならな w。

\section{4) 演算機能}

入カファイルのレコードに対して 4 則演算および条件 式演算を行ない, その結果をワークファイルに出力する。 演算は1 レコードのフィールド間に限られるが，異なっ た 2 つ上のレコード間の演算は，次の作表機能でカハ 一する。

5）作表機能

出力の整理作表を指示する機能であるが，\%指定つォ 


\begin{tabular}{|c|c|c|c|c|c|c|c|}
\hline 项目 & 内 & 容 & 物 & 項目 & 内 & 客 & 例 \\
\hline$T 1$ & 材 & 料 名 & SUS 28 & $\mathrm{~T} 11$ & 第 4 成分湿 & 度 & - \\
\hline T 2 & $\rightarrow ロ$ & 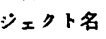 & $\mathbf{A}$ & $\mathrm{T} 12$ & $\mathrm{pH}$ & & - \\
\hline T 3 & 液 & 名 & $\mathbf{A}$ & $\mathrm{T} 13$ & 温 & 度 & - \\
\hline T 4 & 第 1 & 1 成分名 & $\mathrm{HCl}$ & $\mathrm{T} 14$ & 匨 & & ATMOS \\
\hline T 5 & & 筫度 & 2.33 & T15 & 流 & 動 & STAG \\
\hline T 6 & 第 2 & 2 成分名 & $\mathrm{CH}_{3} \mathrm{COOH}$ & $\mathbf{T} 16$ & 応 & 力 & - \\
\hline T 7 & " & " 度 & 15.8 & $\mathrm{~T} 17$ & 武 弱 & 法 & FLASK \\
\hline T 8 & 第 3 & 3 成分名 & $\mathrm{NH}_{4} \mathrm{Cl}$ & $\mathrm{T} 18$ & 侵 食 & 度 & 0.10 \\
\hline T 9 & $"$ & "浱度 & 12.6 & T19 & 食 形 & 態 & PITTING \\
\hline $\mathrm{T} 10$ & 第 4 & 4 成分名 & - & $\mathrm{T} 20$ & 不 動 & 態 & PASSIVE \\
\hline
\end{tabular}

图 3 材料訊験データのファイル

一マット指定, プロセス指定の三機能を持つ。

誌面の都合で精しい説明はできなかったが，詳細は日 本電気（株）の ERPS 説明書2゙を参照せられたい。 ERPS の理解は約 1 日の講義で実用上充分であり, 現在 大ぜいの電算機部門外の人々により使用されている。

\section{2 IRSYM}

本システムは研究室単位で試験データなどを蓄積し, 険索の必要に供する目的で軽便性をねらって開発され た。この場合はファイルの内容は実験記録, 性能カタ口 グ, 調査結果などであろうが, ERPSと異なって,ファ イルの形式は固定してしまっている。したがって，動い ている事務処理に密着して自動的にデータが更新されて いる場合と異なり, データの稚持に特別の努力を傾注せ なばならないことはいらをですない。

機能は次の通りである。

1）ファイル維持

a. 新規作成

b. 更新, 修正, 削除, 追加

2) 質問処理機能

a. 質問分析

b. 検 索

3) 就計処理

a. データ整理, 作表, プロッティング

b. 統計々算

図3に典型的用例として, 装置材料テスト結果のファ イリングへの使用例(゙を示す。材料名, 試験条件, 試 惥結果を表のごとく磁気テープにファイルする。これに 対し希望のデータを抽出する時たとえば下記のごとく記 す。

ID EQ SUS 28*(T4 EQ HCL*T5 GE 5*T5 LE 10 +T6 EQ HCL*T7 GE 5*T7 LE 10)*T13 GE 50*

T18 LE 0.1

（材料 SUS 28 で，液の第 1 組成または第 2 組成が塩 酸で 5 10\% 浱度, かっ $50^{\circ} \mathrm{C}$ 以上で $0.1 \mathrm{~mm} /$ year 以下 の浸触度のデータを抽出せよ。）

IRSYM では上記論理式をカード7枚にわたって記述 することができる。また統計々算処理，ラインプリンタ
$\mathrm{A}$ : フルフォベット, 特殊記号, $\mathrm{N}$ : 数字 $\mathrm{K}$ : カナ文字

\begin{tabular}{|c|c|c|c|}
\hline カードカラム & 内 & 使用文字 & 説 \\
\hline $1 \sim 2$ & カートID & $A, N$ & $\mathrm{AD}$ または 10，3.2.1 参照 \\
\hline $3 \sim 4$ & カードNO & $\mathbf{N}$ & 3.2 .1 萦照 \\
\hline $5 \sim 20$ & 文献番号 & $A, N, K$ & $\begin{array}{l}\text { 左ふめ, 右づめどちらす可 } \\
16 \text { 桁中 } 8 \text { 㭊だけの使用す可 }\end{array}$ \\
\hline $21 \sim 22$ & 分 類 (1) & $A, N$ & \\
\hline $23 \sim 24$ & $" \quad(2)$ & A, $N$ & \\
\hline $25 \sim 44$ & 雑誌名 & $A, N, K$ & \\
\hline $45 \sim 47$ & 巻 & $A, N$ & \\
\hline $48 \sim 51$ & 号 & $\mathrm{A}, \mathrm{N}$ & \\
\hline $52 \sim 55$ & 年 月 & A, N & \\
\hline $56 \sim 65$ & ベージ & $A, N$ & \\
\hline $66 \sim 69$ & 使用せず & & \\
\hline $79 \sim 72$ & 国名, 国䓊 & $A, N, K$ & \\
\hline $73 \sim 74$ & 文献形式 & $A, N$ & $\begin{array}{l}\text { オリシナル, レビンー, レ } \\
\text { ター, 四面, 写真など }\end{array}$ \\
\hline $75 \sim 80$ & インブットID & A, $N$ & 3.2.1 參 \\
\hline
\end{tabular}

Auther カードおよび Title カードは 5〜74カラムを任意に使用する。 䄻題はカード何枚かにわたってる良い。

\section{図 4 DIA の入力様式}

ーによるデータプロッティングす可能である。上式中 $\mathrm{EQ}$ はイコール，GE はミ，LTはく，等々である。括 弧の用法は通常の論理式記述のそれに準ずる。

\section{$4 \cdot 3$ DIA}

DLA はいわゆる文献検索システムとして日本電気 (株)により開発されたものである。味の素（株）にお いては現在のところこれは社内研究報告の整理に利用さ れているが，更に適用範囲を拡大することが目下計画さ れている。

機能の詳細については説明書》を参照されたいが，概 略下記のことくである。

1) アップデート

a）作成（データ内容は图4の通りである。）

b) 追 加

c）执文

d) 削 除

2）索引作成

a）分類索引 入カデータの分類に従って文献表を作成 する。分類のキーは 2 種類

b）書誌リスト 文献番号順に文献表を作成する。

c）著者索引著者名をフルフフベット順に並べ, 文献 番号または文献番号と表題を付す。

d） KWIC 索引 キーワードを中央に固定した形でアル ファベット順に，表題の中に含んで印刷する。この時表 題が 1 行に入りきらぬ分はカットする。国 5 参照。

e） KWOC索引 キーワードを左上飞分離 した形で索 引を作成する。

f）書名索引表題の最初の語をキーワードに文献リス トを作成する。

g）ワード索引 キーワードとして採られた語およびそ の頻度をりストしたものである。

3) $\mathrm{Q} \& \mathrm{~A}$

欲する内容が記载されていそうな文献を抽出するため， 
I HYPOTHESES, PRINCIPLE. MEEDS, RECALL. .

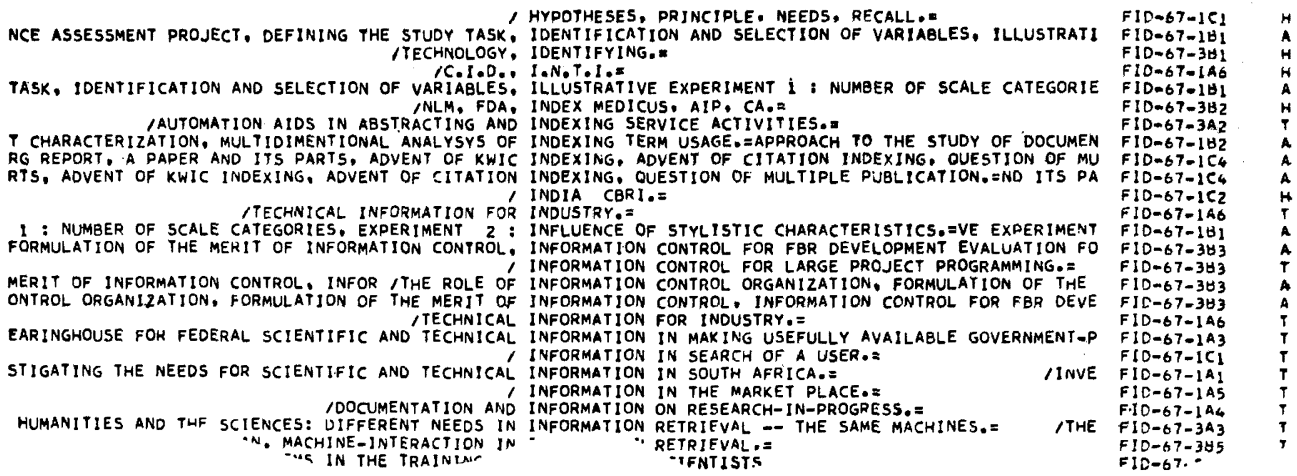

\section{图5KWICインデックスの例}

システム㩫問を発することができる。質問は ERPS， IRSYM と同様論理式形式で記述する。

DIA の場合, 語をキーワート゚として採るかどらかはス トップワードの指定によって行なう。ストップワードと しては冠詞, 前置詞, 接続詞, 助動詞, 副詞, 若干の動 詞・形容詞, 代名詞, 関係代名詞なと150 の他に, 数字, 単独の英字などである。この他にニーザーにより追加す ることができる。指定以外の語がキーワードとなる。

味の素（株）に扮いて，社内の研究報告に本システム を適用をしていることは，前述の通りである。中央研究 所々の他から数多くの研究報告が出されるが，これらを 中央研究所管理部情報課で総括し, 研究成果の共有化, 重複研究の防止などを目的に管理している。研究報告一 件につき，標準様式の研究報告要旨および当報告の配布 先リストを各一葉提出する。配布先はできる限り少数之 し情報課において本文を印刷配布するが，要旨はすべて 全研究開発担当部門に送られる。各部門はこれを整理保 存するが, ハララェティー, 数量ともに豊富であるので, 定期的に DIA による索引を作成発行している。

DIA による索引作成のため現在のところは，研究表 題を英訳しなければならない。これは各著者に任かせ， DIA の大カフォーマットに従った用紙に記載したもの が集められる。DIA はカナ文字の日本語む取り扱うこ とができるが，未たここの使用には踏切っていない。英語 の場合でもストップワード, デリミターなどに関連して 開始時非常に苦労しているので，日本語の讄葉の性質上 慎重にならざるる得ないのであるが，英訳は元来繁雑で あるので, テストは続行したい。

\section{$4 \cdot 4$ GIRLS と FOREST}

いずれも最小 2 乗, 多変量解析, 数量化理諭等高度な 統計々算を主目的に作成したアブリヶーションである。 調查にせよ実験にせよ，個々のデータにはそれが取られ
た個有の状況に関連して種々の影響が交絡する。したが ってデータを取る時は,このようなことを考慮して統計 的に管理された状態で行ならことが望ましく，これが研 究開発の効率化にきわめて有効であることはいらまでる ない。また集積された数多くのデータに対し，統計解析 することによって、データ間に有用な相互関係沶よび法 則性を見いだすことはしばしば可能である。特に後者の 解析は近時諸手法が開発され，経済，需要など諸予測に 多用されて実効をあけ゚ている。かくて大きなデータフ , イルと高度な統計テクニックの組み合わせはプロジェク ト，特にその企画的な面において計算機用法の主流にな りつつある。

始めかかるアプリヶーションの必要性は，多くの統計 々算がマトリクスのローワイズの処理が主となり，した がってそのサブルーチンがローワイズの入力を欲するの に対し，実務的な要請は，項目の取捨などカラムワイズ でのデータの增减にあるための不便さを解決する手段と して発想された。しかしひとたびこの目的のもとに，デ ータファイルとその抽出が可能になると, 必然的にデー タの蓄積と利用ということに考え方が発展する。 GIRIS のフルネームは Generalized Information Retrieval System であり，主機能は統計々算であるが，同時にデ ータ検索システムであることを明らかにし，データメン テナンス他前述して来た諸検索システムと共通の機能を 具えている。

ここで GIRIS はカテゴリーデータなど計数データの 取り扱いに便利であり，FORESTは時系列的整理を された実数データを扱うのに向くよらデザインされてい る。これは計量経凧モデルの分析用システム，たとえば IBM の LEMS 日本電気（秼）の ECONOM などと類 似のものである。

プロジクトにあっては先にす述べたごとく、これら 
システムに常時眝えられるべきデータの選択はきわめて 難かしい。現実的には一群のデータがブロジェクトのあ る時期，二ないし三カ月集中的に検討飞付され，その後 忘れ去られて行く，といらのが通常の姿である。たと えばある新調味料開発のブロジェクトが進行し, 試作品 および調査用紙が数多の消費者バネルに配布されたとす る。調査用紙には各バネルの細かな属性, その調味料の 供試状况，使用秸果，評価などが記載回収される。これ らは一度全データを GIRLSのファイルに貯え，しかる 後多くの角度からの検討が着手される。たとえばデータ の中から，この調味料をサラダに利用して何らかの意見 のあったすのを抽出し，その場合の着眼点について数量 化理論によりおるみつけを行なう。図6はかかる検討を 行なった結果の一例であるが，一般的には解析はその結 果の成否にかかわらず新たな関心を呼び，次々之新しい 啁析の必要を生じつつ次第に情報がしぼりつくされて行 く。このようにして当ファイルへの興味が堿少しつつフ ロジットのフェーズは次段階へと移行して行く。この ような使われ方ああるといらことを理解しておくことす かかるアブリケーションブログラムのデザインには必要 であろう。検討のフェーズをいかにサイクルフッブする か,プロシェクトにとってははなはた重要なことである。

\section{$4 \cdot 5$ その他のテータファイルシステム}

典型的な情報検索システムでないるのでも種々の特殊 な用途のために，データの蓄積・抽出・利用の機能を具 えた種くのアプリケーションが考えられる。既報”の SYCE はラボラトリー段階の初期の実験成績から、コス トエスティメーションを迅速に行ならため, コストデー タのファイリングが考えられている。規格のファイルか らのマトリックスゼネレーションなどを検討したことる ある。また物性定数のファイリングは各所で試みられて いるが，状態の变化や他成分の影響などについての強力 な推算法と結びつくときわめて有効なるのになるのでは なかららか。

\section{ま と め}

高度生長経済の中で, 工場ブロジェクトの比重はから てない大きなものとなりつつあるが，その内容も過去に 例をみない難かしいるのとなってきた。この面の生産性 を向上するために電算機の利用はきわめて有効なすのと 考えられるか，ここには定型定常的な事務計算，あるい はプロセスコントロールには見られない問題点がある。 一言にして言えば, 不特定かつ常に新しい対象に対し，迅

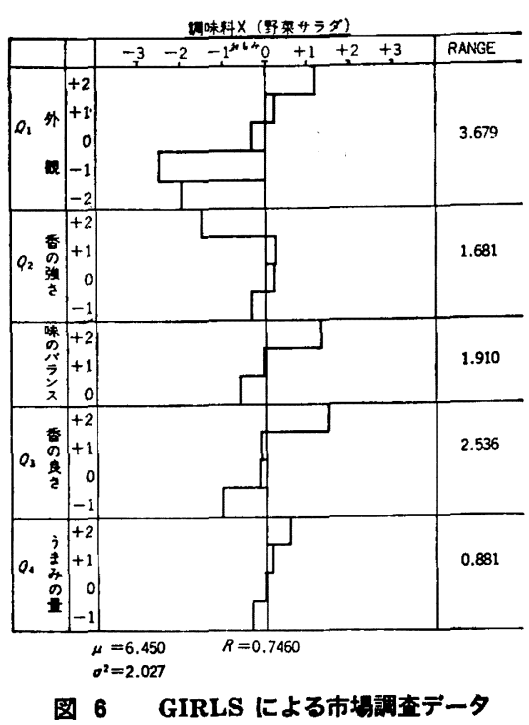

速にサービスを達成して行かねばならないことである。

ブロジェクトの効率向上に有效であり，かつ計算機効 率む高く保つため, 最大多数のブロジェクトのニーズに 基ついた沉用性の高いフプリケーションプログラムの蓄 積が先ず必要である。これらの利用は万人向きに簡易で あることと同時に，実質的かつ広範な教育がフォローし なければならない。

プロジェクトの業務が本質的には情報の生産授受がそ の主体である以上，情報の蓄積・選別・利用が電算機 ブリヶーションの中でる重要な位置をしめることは言う まですない。この面に対し総合化, システム化は常に担 当者の理想とするところであるが, ブロジェクト業務の 広範さ、データの性質のバラェティー、その利用方法の 多様性から、なかなかそれを現実のるのにすることは難 かしい。

“情報検索”といら言葉を広義に解して，味の素（株） で使用されているフブリヶーションの中からその範囲に 入りそうな幾つかのすのを紹介した。これらの作成ない 乙利用の意図は本節前段に述へらられた通りであるが，い ずれはデータの集中管理のセンターとしての着眼点で根 本から眺め直す必要があるものと考えている。

\section{文献}

1) 富田5: 化学工学, 31, [1], 10 (1967)

2) 日本電文 (株) ERPS 説明望 (1969)

3）小缕与：防食技街，18，[5]，16 (1969)

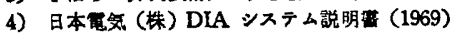

